\title{
Field observations of the dinoflagellate genus Azadinium and azaspiracid toxins in the south-west Atlantic Ocean
}

\author{
Elena Fabro ${ }^{\mathrm{A}, \mathrm{B}, \mathrm{D}}$, Gastón O. Almandoz ${ }^{\mathrm{A}, \mathrm{B}}$, Bernd Krock ${ }^{\mathrm{C}}$ and \\ Urban Tillmann ${ }^{\text {Ć }}$ \\ A División Ficología, Facultad de Ciencias Naturales y Museo, Universidad Nacional de La Plata, \\ Paseo del Bosque s/n (B1900FWA), La Plata, Argentina. \\ ${ }^{B}$ Consejo Nacional de Investigaciones Científicas y Técnicas (CONICET), Avenida Rivadavia \\ 1917, 1033 Buenos Aires, Argentina. \\ ${ }^{C}$ Alfred Wegener Institut-Helmholtz Zentrum für Polar- und Meeresforschung, Chemische \\ Ökologie, Am Handelshafen 12, D-27570 Bremerhaven, Germany. \\ ${ }^{D}$ Corresponding author. Email: fabroelena@yahoo.com.ar
}

\begin{abstract}
Some dinoflagellate species of the genera Azadinium and Amphidoma (Amphidomataceae) produce azaspiracids (AZA), a group of toxins responsible for gastrointestinal disorders in humans following the consumption of contaminated shellfish. In this study, we investigated the diversity, distribution and abundance of Azadinium and AZA from field plankton samples collected during four oceanographic expeditions that covered an extended area of the Argentine Sea during different seasons. Scanning electron microscopy analyses indicated the presence of five Azadinium species: Az. dexteroporum, Az. luciferelloides, Az. obesum, Az. asperum and Az. cf. poporum. Azadinium-like cells were frequently found and were even an abundant component of plankton assemblages, showing a wide latitudinal distribution, from $\sim 38$ to $\sim 55.5^{\circ} \mathrm{S}$, and occurring in a wide temperature and salinity range. High cell densities (up to $154000 \mathrm{cells}^{-1}$ ) occurred in northern slope and external shelf waters during spring. AZA-2 was detected in net samples from the 20- to 200- $\mu \mathrm{m}$ fractions by tandem mass spectrometry-liquid chromatography analysis, suggesting a transfer of AZA through the food web. Our results contribute to the knowledge of the worldwide occurrence of Azadinium species and AZA, and highlight the importance of amphidomatacean species as a potential source of AZA shellfish poisoning in the south-west Atlantic Ocean.
\end{abstract}

Additional keywords: Azadinium asperum, Azadinium dexteroporum, Azadinium luciferelloides, Azadinium obesum, Azadinium cf. poporum, azaspiracid-2.

Received 6 April 2019, accepted 27 August 2019, published online 13 November 2019

\section{Introduction}

The consequences of harmful algal blooms related to phycotoxin transfer through the food web, which includes effects on public health, fauna mortality and negative repercussions on the marine ecosystem, seem to have increased since the 1960s. Similarly, new phycotoxins and toxin-producing species have been discovered in recent years; of these, the most recent examples are the dinoflagellate family Amphidomataceae (which includes species of Azadinium and Amphidoma) and their toxins, azaspiracids (AZAs; Lassus et al. 2016). To date, 26 AZAs have been reported from dinoflagellate origin (Krock et al. 2019). Some of these have been known since the 1990s as the source of human intoxications by AZAs, a syndrome called azaspiracid shellfish poisoning (Satake et al. 1998) that includes severe gastrointestinal disorders after ingestion of contaminated seafood (Twiner et al. 2014). At present, the genus Azadinium consists of 13 species (Tillmann et al. 2014a; Tillmann and Akselman 2016; Luo et al. 2017; Tillmann 2018), of which 11 have been tested for AZA production and three (Azadinium spinosum, Azadinium dexteroporum and Azadinium poporum) have shown the capacity to synthesise AZA (Tillmann et al. 2009; Krock et al. 2012; Rossi et al. 2017). Only two of the 16 species of the genus Amphidoma have been tested for the production of AZA, with Amphidoma languida (Krock et al. 2012), but not Amphidoma parvula (Tillmann et al. 2018a), proven to produce AZA.

Most Azadinium species are small $(<20 \mu \mathrm{m})$ and their morphological identification requires detailed scanning electron microscopy (SEM) to reveal plate patterns and other diagnostic characteristics at the species level, such as the presence or absence of an antapical spine, the location of the ventral pore and some specific characteristics of diagnostic plates, such as Plate 2a (Tillmann et al. 2009, 2010, 2012a, $2012 b, 2014 a$ ). Consequently, identification of Azadinium is complex and thus little is known regarding their worldwide distribution. However, the wide distribution of AZA analogues 
detected in shellfish samples (e.g. Braña Magdalena et al. 2003; Taleb et al. 2006; Elgarch et al. 2008; Vale et al. 2008; Álvarez et al. 2010; Yao et al. 2010; Trainer et al. 2013; Krock et al. 2014; Bacchiocchi et al. 2015; Turner and Goya 2015) indicates that AZA-producing Amphidomataceae species are cosmopolitan.

Records of Amphidomataceae for the southern Atlantic continental shelf may be traced back to the mid-1970s when Campodónico and Guzmán (1974) described a dense bloom $\left(6.8 \times 10^{5}\right.$ cells L $\left.{ }^{-1}\right)$ of Amphidoma sp. in the Magallanes Strait that, interestingly, coincided with a mild case of human intoxication after shelf consumption. However, Campodónico and Guzmán (1974) did not provide micrographs, drawings or any morphological description other than size (and that cells have spines) in their report, so the identification of the causative species as Amphidoma is rather doubtful and needs confirmation. In the Argentine Sea, the first record of Amphidomataceae corresponds to one cell of an unidentified species of Amphidoma found by Balech (1988) in northern slope waters $\left(\sim 39^{\circ} \mathrm{S}\right.$, $\left.52^{\circ} \mathrm{W}\right)$. After that, two Amphidomataceae spring blooms were registered in 1990 and 1991 from slope waters adjacent to Mar del Plata, Buenos Aires Province $\left(\sim 39^{\circ} \mathrm{S}\right)$ and from the middle shelf of an area neighbouring El Rincón, Buenos Aires Province ( 40 $\mathrm{S}$; Akselman and Negri 2012). The 1990 bloom generated water discolouration that lasted for 1 week and covered an area of $\sim 60 \mathrm{~km}^{2}$. The maximum cell density of $9 \times 10^{6}$ cells $\mathrm{L}^{-1}$ (Akselman and Negri 2012) represents the biggest Azadinium bloom thus far. The presence of an antapical spine and a pyrenoid in the cells led Akselman and Negri (2012) to identify the cells as Azadinium cf. spinosum, one of the three Azadinium species described at that time. However, some taxonomic characteristics, such as the location of the ventral pore, could not be observed. Later, a third bloom was recorded in late winter 1998 in the same area as the 1990 bloom, again causing water discolouration; the cells in this case were also characterised as Az. cf. spinosum (Akselman et al. 2014). However, a reexamination of the 1990 bloom samples with SEM revealed that a newly described species, Azadinium luciferelloides, was the dominant species in the community (Tillmann and Akselman 2016), and one additional species of Azadinium (Azadinium asperum) and three new Amphidoma species (Am. trioculata, Am. cyclops and Am. alata), in addition to the SEM record of Am. languida were also described (Tillmann 2018). The first Azadinium strains from Argentina were Az. poporum, established from sediment samples collected from a highly productive area of coastal waters off Buenos Aires Province (El Rincón), with toxin analysis showing profiles consisting exclusively of AZA-2 (Tillmann et al. 2016). Based on a survey in 2015 across El Rincón to the outer shelf area, light microscopy and polymerase chain reaction (PCR) analysis revealed that Amphidomataceae were widely present and abundant in spring plankton communities, but AZA could not be detected in the plankton (Tillmann et al. 2019). From this survey, several strains of Azadinium dalianense and Az. spinosum and a strain of the newly described Am. parvula were established. Toxin analyses showed that all $A z$. dalianense and most Az. spinosum strains were non-toxigenic, except for one strain that produced only AZA-2 (Tillmann et al. 2019). Regarding detection of AZAs in Argentinean mussels, low levels of AZA-2 were detected in shellfish from Santa Teresita and San Clemente del Tuyú, Buenos Aires Province (Turner and Goya 2015).

Despite these previous reports of Azadinium and AZAs, information about their diversity and distribution remains limited and restricted to the northern Argentine Sea. Even though the identification and quantification of toxigenic Amphidomataceae species is challenging, particularly because both toxigenic and non-AZA-producing species occur in the same area (Tillmann et al. 2010, 2011, 2012b, 2019), it is important to determine the occurrence of Azadinium and Amphidoma species and the presence of AZA in the south-west Atlantic. The aim of the present study was to analyse the abundance and spatiotemporal distribution of Amphidomataceae species in field populations from an extended area of the Argentine Sea coupled with field sample AZA analysis and electron microscopy for species identification.

\section{Material and methods}

\section{Field sampling protocols}

The continental shelf waters of the Argentine Sea were sampled during four oceanographic expeditions. Expedition 1 (E1) was conducted in austral autumn onboard $R / V$ Puerto Deseado from 30 March to 14 April 2012. In all, 46 stations were sampled between $\sim 38$ and $56^{\circ} \mathrm{S}$. The second expedition (E2) was conducted in late austral summer on $R / V$ Bernardo Houssay from 11 to 22 March 2013, with 24 sampling stations located between $\sim 39$ and $43^{\circ} \mathrm{S}$. This cruise was divided in two legs, $\mathrm{K} 1$ and $\mathrm{K} 2$, which comprised 8 and 16 sampling stations respectively. The third expedition (E3) was conducted in austral spring aboard $R / V$ Puerto Deseado, from 26 October to 9 November 2013, with 47 sampling stations located between $\sim 40$ and $47^{\circ} \mathrm{S}$. Finally, the fourth expedition (E4) was conducted on $R / V$ Bernardo Houssay in austral summer from 6 to 12 January 2016, with seven sampling stations located between $\sim 42$ and $55^{\circ} \mathrm{S}$. The conductivity, temperature and depth (CTD) data were available throughout all expeditions, except from K2 of E2, during which no CTD measurements were made. During this leg, only surface water temperature was measured with a multiparameter probe (Model WQC; TOA-DKK Corporation, Tokyo, Japan).

Plankton samples were collected by vertical net tows through the upper $20 \mathrm{~m}$ of the water column using a $20-\mu \mathrm{m}$ mesh Nitex net $60 \mathrm{~cm}$ in diameter for both taxonomic and phycotoxin analysis. Each net haul concentrate was adjusted to $1 \mathrm{~L}$ with $0.2 \mu \mathrm{m}$ of filtered seawater. A $100-\mathrm{mL}$ aliquot was fixed with acidic Lugol's iodine solution for species identification and enumeration. The rest was sequentially filtered through Nitex mesh of 200, 50 and $20 \mu \mathrm{m}$ in polyvinyl chloride (PVC) cylinders by gravity filtration. The particulate material retained on each mesh was resuspended in $40 \mathrm{~mL}$ of filtered seawater and transferred to 50-mL centrifuge tubes. Each size fraction concentrate was split into two $20-\mathrm{mL}$ aliquots for lipo- and hydrophilic toxin analyses. The aliquots were centrifuged at $3220 \mathrm{~g}$ for $15 \mathrm{~min}$ at room temperature. The pellets were stored at $-20^{\circ} \mathrm{C}$ for later toxin analysis. During all four expeditions, Niskin bottle samples were taken from depths of 3 and $10 \mathrm{~m}$, mixed in equal volume and fixed with acidic Lugol's iodine solution for quantitative analysis of phytoplankton. For AZA analysis, 2or 3-L samples of this mixture were filtered through a $3-\mu \mathrm{m}$ 

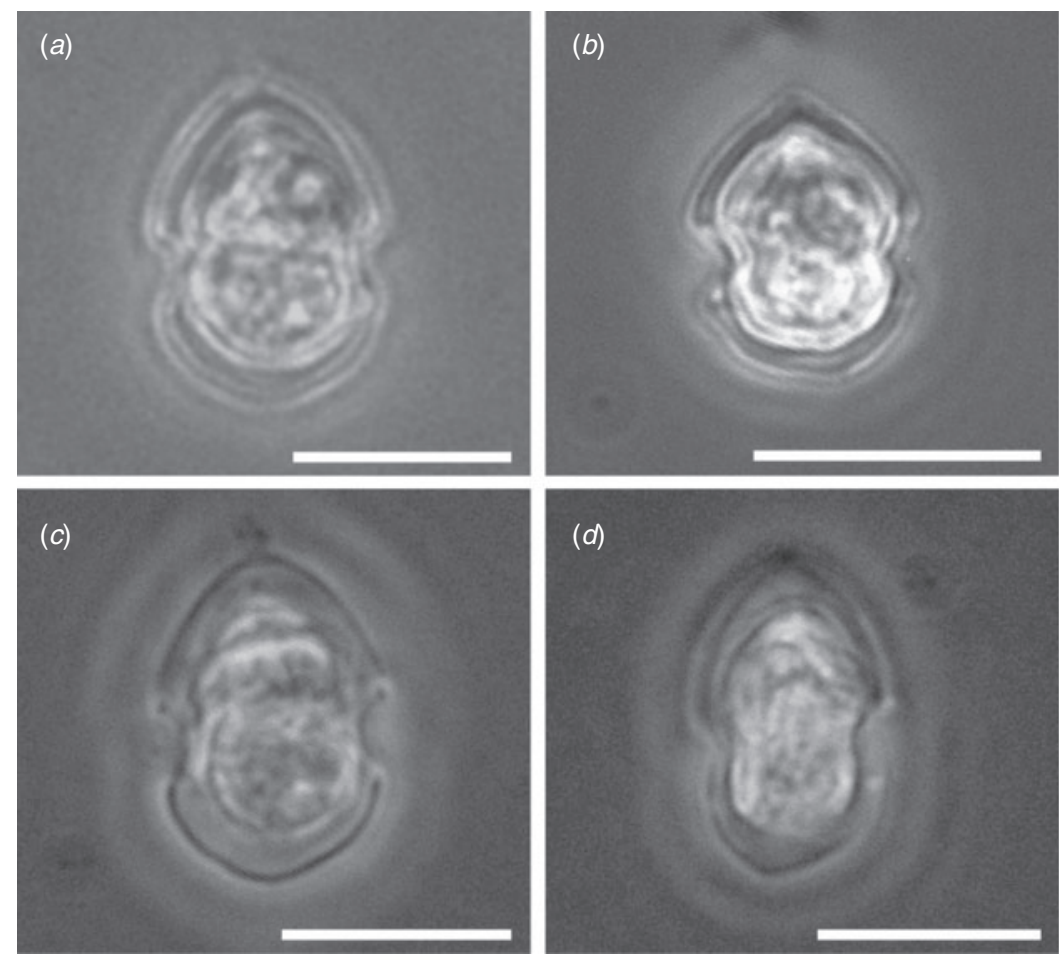

Fig. 1. Light microscopy images of Azadinium-like cells found in Lugol-fixed bottle samples. Scale bars: $10 \mu \mathrm{m}$.

(E1-E3) or 5- $\mu \mathrm{m}$ (E4) pore polycarbonate filter. Filters were placed with their back to the inner wall of a $50-\mathrm{mL}$ centrifuge tube (Sarstedt, Nümbrecht, Germany) and kept at $-20^{\circ} \mathrm{C}$ for less than 2 months until analysis.

\section{Plankton analysis}

The abundance of nano- $(\sim 5-20 \mu \mathrm{m})$ and microplankton $(20$ $200 \mu \mathrm{m})$ was estimated using the Utermöhl (1958) inverted microscope method. Subsamples $(50 \mathrm{~mL})$ from the mixed water obtained using Niskin bottles were left to settle for $24 \mathrm{~h}$ in a composite sedimentation chamber before cell counting. At least 300 cells of the dominant taxa were counted in random fields or in half the chamber to estimate general plankton composition, whereas the whole chamber bottom was scanned to count less abundant species. Plankton taxa from the 5- to $200-\mu \mathrm{m}$ size range, including photosynthetic and heterotrophic protists, were identified to the highest possible taxonomic level (i.e. species). However, some small flagellates $(\sim 5-10 \mu \mathrm{m})$ that lost their flagella during fixation were included in a single group as 'small unidentified flagellates'. In particular, dinoflagellate abundance includes cells with and without plastids. During plankton counting, small thecate dinophytes that were between $\sim 7$ and $18 \mu \mathrm{m}$ long and had a pointed apex and a wide cingulum (Fig. 1) were counted in the category of Azadinium-like cells, but it has to be kept in mind that such a category probably also includes Amphidoma sp. and may also contain small Heterocapsa species; thus, cell abundances may be overestimated. The limit of detection of this method was 20 cells $\mathrm{L}^{-1}$ for the three expeditions.
Further morphological examination of selected samples was conducted with three SEMs: Jeol JSM-6360 LV SEM (JEOL, Tokyo, Japan), Carl Zeiss NTS SUPRA 40 (Zeiss, Oberkochen, Germany) and FEI Quanta FEG 200 (FEI, Eindhoven, Netherlands). Aliquots $(50 \mathrm{~mL}$ ) of bottle samples were filtered through $0.2-\mu \mathrm{m}$ polyamide filters for SEM analyses. The material on the filters was dehydrated by serial ethanol treatment $(25,50,75$ and $100 \%)$ and final critical point dehydration (BAL-TEC CPD-30; BAL-TEC, Balzers, Liechtenstein). Specimens were sputter-coated with $\mathrm{Au}$ with an iron sputter fine coat Jeol JFC 1.100 (JEOL) before examination. The following samples were analysed by SEM: I9, I13 and I15 from E1; $3 \mathrm{~K} 1,9 \mathrm{~K} 2,10 \mathrm{~K} 2$ and 20K2 from E2; 1, 3-7, 25, 43 and 44 from $\mathrm{E} 3$; and 4 and 5 from E4.

\section{Toxin analysis}

Cell pellets obtained from net samples were suspended in $500 \mu \mathrm{L}$ methanol, and subsequently homogenised with $0.9 \mathrm{~g}$ of Lysing Matrix D (Thermo Savant, Illkirch, France) by reciprocal shaking at maximum speed $\left(6.5 \mathrm{~m} \mathrm{~s}^{-1}\right)$ for $45 \mathrm{~s}$ in a Bio101 FastPrep instrument (Thermo Savant, Illkirch, France). After homogenisation, samples were centrifuged at $16100 \mathrm{~g}$ for $15 \mathrm{~min}$ at $4^{\circ} \mathrm{C}$. The supernatant was transferred to a spin filter (pore size $0.45 \mu \mathrm{m}$; Millipore Ultrafree, Eschborn, Germany) and centrifuged at $800 \mathrm{~g}$ for $30 \mathrm{~s}$ at room temperature, followed by transfer to autosampler vials. Toxin concentrations are expressed as nanograms per net tow.

For bottle sample analysis of AZA, polycarbonate filters were repeatedly rinsed with $500-1000 \mu \mathrm{L}$ of methanol until 

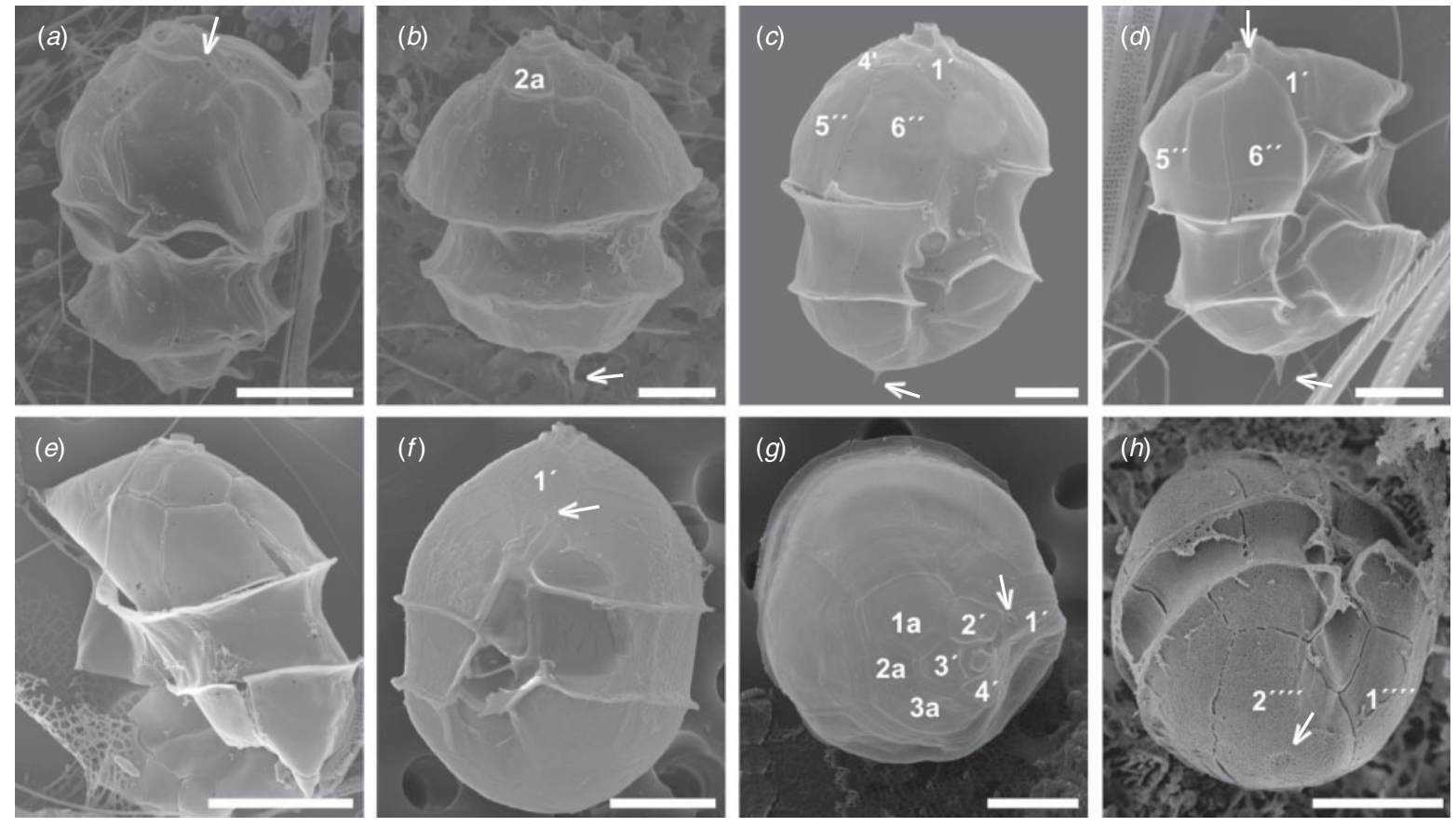

Fig. 2. Scanning electron microscopy images of Azadinium cells from the Argentine Sea. ( $a, b)$ Azadinium dexteroporum. (a) Lateral view; note the location of the ventral pore (vp) at the right margin of the pore plate (arrow). (b) Dorsal view; note the presence of an antapical spine (arrow) and the concave shape of Plate 2a. ( $c-e)$ Azadinium luciferelloides. $(c, d)$ Ventral views; note the presence of an antapical spine (arrows) and the location of the vp at the right side of the pore plate (d; arrow). (e) Dorsal view. ( $f$ ) Azadinium obesum ventral view; note the position of the vp at the left side of Plate $1^{\prime}$ (arrow). (g) Azadinium asperum apical view; note the location of the vp in the left region of Plate $1^{\prime}$ at the end of the suture between Plates $1^{\prime}$ and $2^{\prime}$ (arrow). (h) Azadinium cf. poporum antapical view; note the group of pores in Plate $2^{\prime \prime \prime \prime}$ (arrow). Scale bars: $2 \mu \mathrm{m}(a-d) ; 5 \mu \mathrm{m}(e-h)$.

complete discolouration of the filters. The methanolic extracts were transferred to a spin filter (pore size $0.45 \mu \mathrm{m}$; Millipore Ultrafree), and centrifuged at $800 \mathrm{~g}$ for $30 \mathrm{~s}$ at $4^{\circ} \mathrm{C}$, followed by transfer to autosampler vials. AZA concentrations in samples were determined using liquid chromatography-tandem mass spectrometry (LC-MS/MS), as described by Luo et al. (2016).

The following AZA analogues were included in bottle and net samples analysis: 1, 2, 11,33-43, 54-59 and 62 .

\section{Results}

\section{Species identified}

Five Azadinium species were identified by SEM analysis of field samples: Az. dexteroporum $(n=15)$, Az. luciferelloides $(n=5)$, Az. obesum $(n=4), A z$. asperum $(n=1)$ and Az. cf. poporum $(n=3)$. No Amphidoma species were identified by SEM analysis of field samples.

The identification of $A z$. dexteroporum was based on the location of the ventral pore (vp) at the end of an asymmetrical elongation of the pore plate $(\mathrm{Po})$ and by the particular shape of the intercalary Plate $2 \mathrm{a}$, which was concave, forming a depression on the theca (Fig. 2a,b). Az. luciferelloides was identified by the position of the vp at the right side of the Po and by the antapical spine. In addition, the presence or absence and arrangement of thecal pores (diameter 0.05-0.15 $\mu \mathrm{m}$ (mean $0.1 \mu \mathrm{m}) ; n=27$ ) was also consistent with the species description (Fig. $2 c-e$ ). The identification of Az. obesum was based on the location of the vp at the posterior left side of Plate $1^{\prime}$, by the absence of a antapical spine and by a slightly larger size of the cells (Fig. 2f). Az. asperum was characterised by the presence of an antapical spine and by the location of the vp in the anterior left region of Plate $1^{\prime}$. Az. asperum could also be differentiated from other Azadinium by the presence of a rugged theca (Fig. $2 g$ ). Finally, a few cells without an antapical spine and with a group of 5-10 pores on Plate $2^{\prime \prime \prime \prime}$ were identified as $A z$. cf. poporum (Fig. 2h).

\section{Azadinium abundance and distribution \\ Autumn expedition (E1)}

Azadinium-like cells were found in 15 of 47 bottle samples at cell densities ranging between 20 and 4000 cells $\mathrm{L}^{-1}$ and representing between 0.4 and $31 \%$ of total dinoflagellate abundance (mean 10\%). Maximum abundance of Azadinium-like cells was found in the southern sampling area $\left(55^{\circ} \mathrm{S}\right)$, in shelf waters from Tierra del Fuego Province and Isla de los Estados (Fig. 3). At these stations (I9, I13 and I15), concentrations of total planktonic protists reached $1.1-5.6 \times 10^{5}$ cells $\mathrm{L}^{-1}$, and these were primarily represented (i.e. $69-97 \%)$ by small $(\sim 5-10 \mu \mathrm{m})$ unidentified flagellates. Dinoflagellate abundance in those samples was 9-14 $\times 10^{3}$ cells L ${ }^{-1}$ (which represented 2-11\% of total planktonic protists) and dinoflagellates were primarily represented by unidentified small gymnodinioids $\left(2.5-8.1 \times 10^{3}\right.$ cells $\left.\mathrm{L}^{-1}\right)$. Azadinium-like cells were present at lower densities (20$10^{3}$ cells $\mathrm{L}^{-1}$ ) in another seven samples from that area, which showed a similar plankton composition as reported for 
Stations I9, I13 and I15. However, in five samples of the San Jorge Gulf, where Azadinium-like cells were also found, plankton composition was considerably different from that of the southern stations. In four of those samples (C43, C43N, C44 and C45) dinoflagellates were the dominant group, being present at densities between $6 \times 10^{3}$ and $34 \times 10^{3}$ cells $\mathrm{L}^{-1}$, and primarily represented by the genus Tripos. At Station $\mathrm{P} 45 \mathrm{~B}$, diatoms dominated the community, with an abundance of $6 \times 10^{3}$ cells $\mathrm{L}^{-1}$ and primarily represented by Thalassiosira $\mathrm{sp}$.

During the whole cruise, Azadinium-like cells were detected over a temperature range of $6-14^{\circ} \mathrm{C}$ and at salinities ranging from 31.2 to 34.2. Maximum Azadinium-like cell densities were found at temperatures between 7.8 and $8.6^{\circ} \mathrm{C}$ and at salinities of 32.6-33.7. The temperature range for this expedition was $6-19^{\circ} \mathrm{C}$ and the salinity range was $31.2-34.2$.

Through the concentration of bottle samples from Stations I9, I13 and I15, obtained in the southern Argentine Sea $\left(\sim 55^{\circ} \mathrm{S}\right)$, it was possible to identify two Azadinium species: Az. dexteroporum and Az. cf. poporum (Fig. 3).

\section{Late summer expedition (E2)}

Azadinium-like cells were detected in 22 of 25 bottle samples, with cell abundances ranging from 20 to 19000 cells $\mathrm{L}^{-1}$ and representing $0.3-53 \%$ of total dinoflagellate abundance (mean 17\%). The maximum abundance of Azadinium-like cells was found in southern San Matías Gulf, at Station 10K2 (Fig. 4). At this station, total phytoplankton abundance was $3.4 \times 10^{5}$ cells $\mathrm{L}^{-1}$, and there was a high contribution of dinoflagellates (34\%), primarily represented by Prorocentrum cordatum. Unidentified small $(<10 \mu \mathrm{m})$ flagellates were dominant at all samples with Azadinium-like cells, except for samples corresponding to Valdés Peninsula, where cryptophytes were the dominant group. In addition, although abundance was lower $\left(<5000\right.$ cells L $\left.{ }^{-1}\right)$, Azadinium-like cells represented more than $30 \%$ of total dinoflagellates at Stations $6 \mathrm{~K} 1$ (southern Buenos Aires Province), 20K2, 21K2 (San Matías Gulf) and 28K2 (Valdés Peninsula), with total planktonic protist abundances of $0.7-1.8 \times 10^{5}$ cells $\mathrm{L}^{-1}$ and dinoflagellate densities of $0.02-0.1 \times 10^{5}$ cells $\mathrm{L}^{-1}$. Diatoms, primarily represented by Guinardia delicatula, dominated at Station 20K2.

Azadinium-like cells were found in a temperature range of $15-19^{\circ} \mathrm{C}$ and at salinities ranging from 31.9 to 34.1 . Maximum Azadinium-like cell density was found at $16.2^{\circ} \mathrm{C}$. The temperature range during E2 was $14-19^{\circ} \mathrm{C}$ and salinity ranged between 31.9 and 34.1 .

It was not possible to identify Azadinium cells from this expedition to species level because SEM analyses did not enable enough taxonomic features to be seen to assign cells to a particular species.

\section{Spring expedition (E3)}

Azadinium-like cells were found in 26 of 44 bottle samples, at cell densities ranging from 20 to $1.5 \times 10^{5}$ cells $\mathrm{L}^{-1}$ and representing between 0.05 and $87 \%$ of total dinoflagellate abundance (mean 21\%). In 10 samples, Azadinium-like cells accounted for more than $30 \%$ of total dinoflagellate abundance. Eight of those samples were from stations located in slope waters (Stations 1, 4, 5, 6, 7, 39, 43 and 44) with total

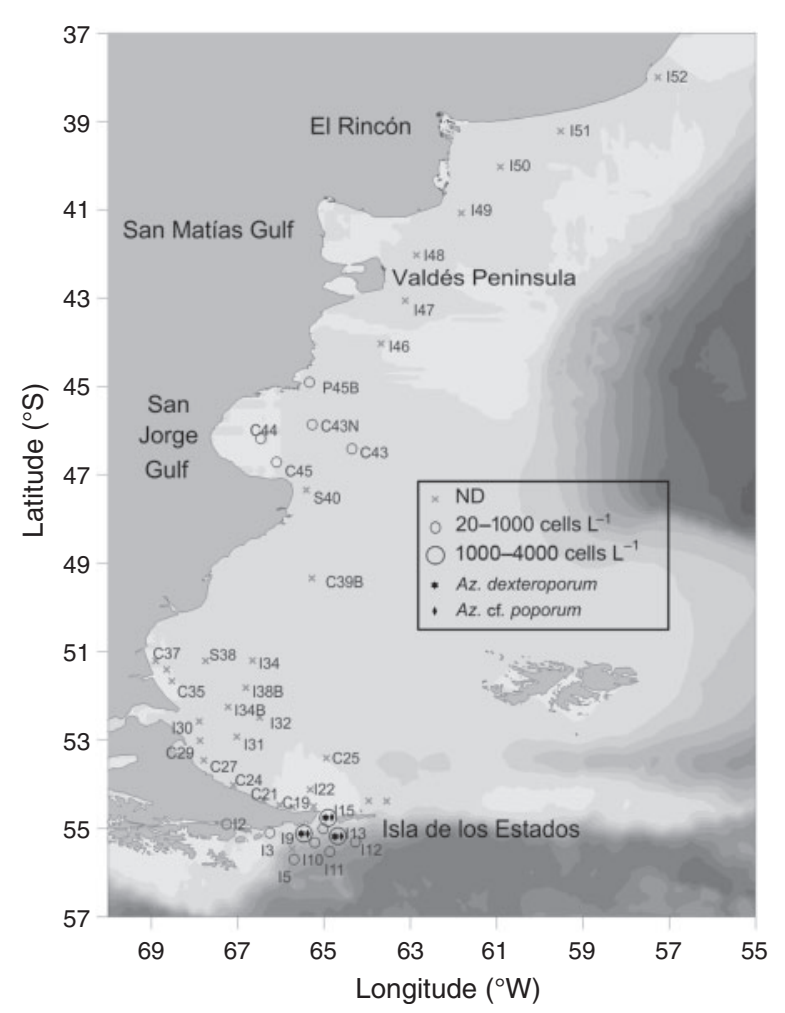

Fig. 3. Distribution and abundance of the Azadinium-like cells in bottle samples from the autumn 2012 expedition (Expedition 1). ND, not detected.

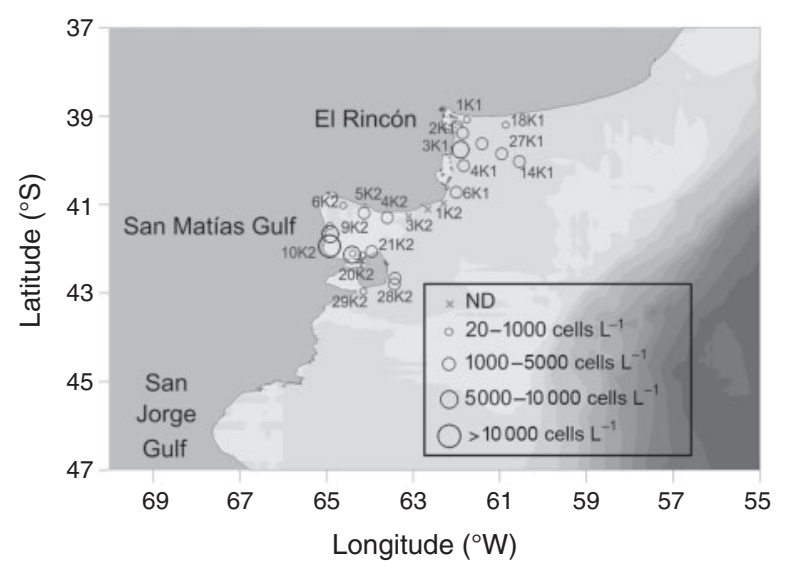

Fig. 4. Distribution and abundance of Azadinium-like cells in bottle samples from the late summer 2013 expedition (Expedition 2). ND, not detected.

plankton abundances of $0.8-40.4 \times 10^{5}$ cells $\mathrm{L}^{-1}$ and dominated by diatoms (primarily Hemiaulus sp., Helicotheca tamesis and Thalasiossira sp.), with the exception of samples from Station 6, which was dominated by dinoflagellates (primarily Protoperidinium sp., with an abundance of $0.2 \times 10^{5}$ cells L $^{-1}$ ), and Station 39, which was dominated by small unidentified flagellates. At the other two stations, Stations 14 and 25, total planktonic protists abundance was $120.6 \times 10^{5}$ and 


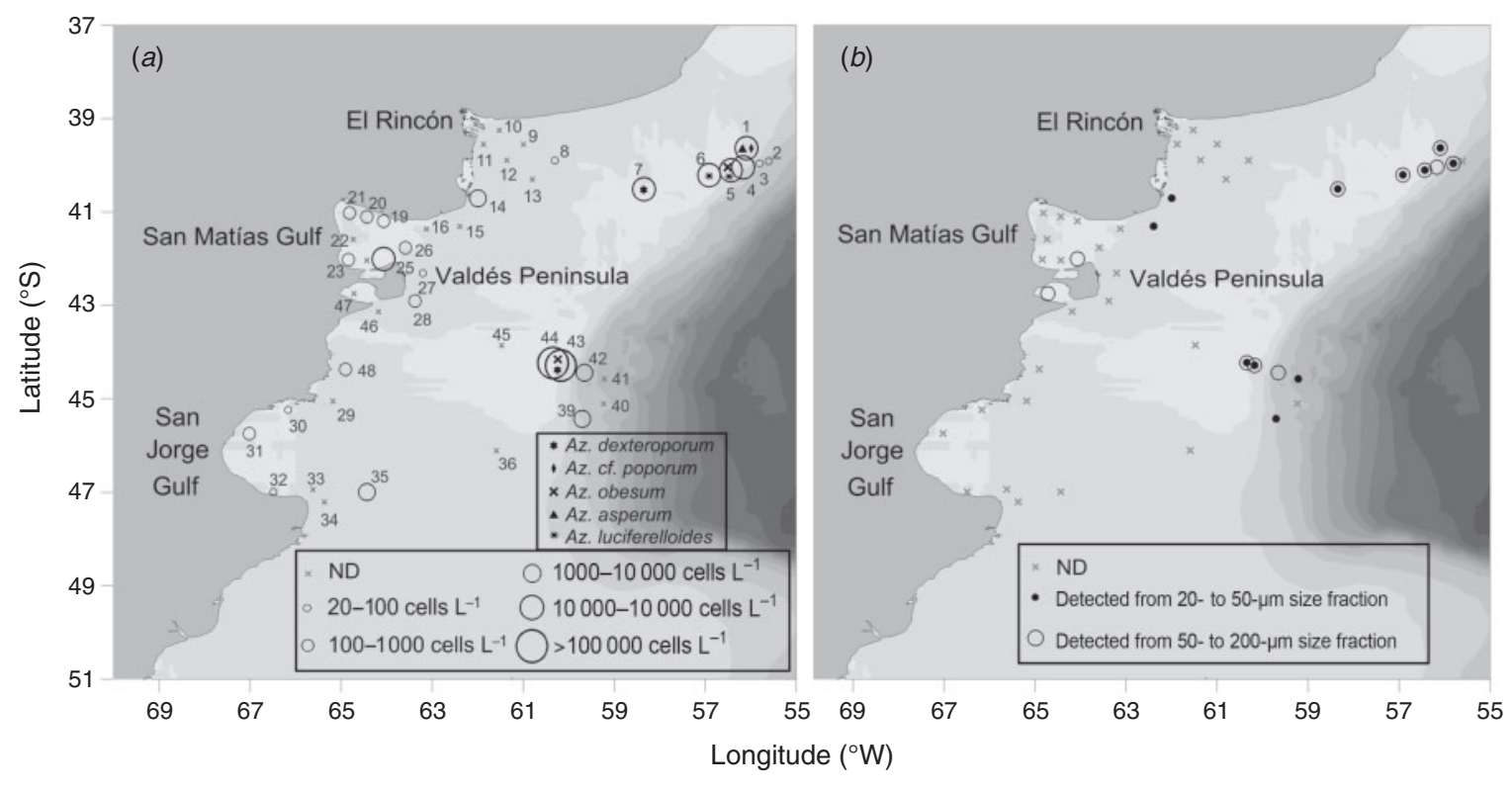

Fig. 5. (a) Distribution and abundance of Azadinium-like cells in bottle samples and (b) azaspiracid (AZA)-2 distribution in net samples from the spring 2013 expedition (Expedition 3). ND, not detected.

$34.7 \times 10^{5}$ cells $\mathrm{L}^{-1}$ respectively, and the dominant groups were small unidentified phytoflagellates and haptophytes respectively. Maximum abundance of Azadinium-like cells was detected at Stations 43 and 44 located in slope waters between 40 and $44^{\circ} \mathrm{S}$ (Fig. 5a), in which the maximum abundance of Gyrodinium fusus $\left(10-11 \times 10^{3}\right.$ cells L $\left.{ }^{-1}\right)$ was also recorded. At Stations 14 and 35, moderate densities $\left(1-10 \times 10^{3}\right.$ cells $\left.\mathrm{L}^{-1}\right)$ of Azadinium-like cells were found and total plankton abundance was $120.7 \times 10^{5}$ and $10.5 \times 10^{5}$ cells $\mathrm{L}^{-1}$ respectively. In samples from both Stations 14 and 35, unidentified small flagellates were dominant $\left(120.0 \times 10^{5}\right.$ and $9.2 \times 10^{5}$ cells $\mathrm{L}^{-1}$ respectively), but a high abundance $\left(37.5 \times 10^{3}\right.$ cells $\left.\mathrm{L}^{-1}\right)$ of the diatom Asterionellopsis sp. was found at Station 14 and prasinophytes, with a cell density of $100 \times 10^{3}$ cells $\mathrm{L}^{-1}$, were the secondmost abundant group at Station 35 .

Azadinium-like cells were present at temperatures ranging from 8 to $13.5^{\circ} \mathrm{C}$ and at salinities ranging from 33 to 34.1 . Maximum Azadinium-like cell densities were detected between 9.4 and $9.7^{\circ} \mathrm{C}$ and at a salinity of 33.7. The temperature range for this expedition was $7-15^{\circ} \mathrm{C}$ and the salinity range was $32.9-4.2$.

SEM analyses enable identification of five species: Az. obesum, Az. dexteroporum, Az. luciferelloides, Az. asperum and $A z$. cf. poporum. The presence of Az. asperum and $A z$. cf. poporum was confirmed at Station 1 and Az. luciferelloides was confirmed at Stations 5 and 6, all corresponding to northern slope waters $\left(\sim 40^{\circ} \mathrm{S}\right)$. Az. obesum was found at Stations 5 and 43, whereas Az. dexteroporum was detected at Stations 7, 43 and 44 , all from northern $\left(\sim 40^{\circ} \mathrm{S}\right)$ and central $\left(\sim 44^{\circ} \mathrm{S}\right)$ slope waters (Fig. 5a).

Azadinium-like cells were also found by light microscopy in three net samples from the 20 - to $50-\mu \mathrm{m}$ size fractions of Stations 1, 6 and 26, and in one sample of the $50-$ to $200-\mu \mathrm{m}$ fraction of Station 1.

\section{Early summer expedition (E4)}

Azadinium-like cells were found in four of seven bottle samples, with densities between 100 and 3000 cells L $^{-1}$ and representing $1.5-10 \%$ of total dinoflagellate abundance (mean $4 \%$ ). Maximum cell densities were found in southern San Jorge Gulf $\left(47^{\circ} \mathrm{S}\right.$; Fig. 6) in samples with a total phytoplankton abundance of $10.8-17.5 \times 10^{5}$ cell $\mathrm{L}^{-1}$ and dominated by small unidentified flagellates. At those stations dinoflagellates reached high abundances $\left(34-128 \times 10^{3}\right.$ cells $\left.\mathrm{L}^{-1}\right)$, primarily due to the heterotrophic G. fusus. At the other two stations with Azadinium-like cells, Stations 6 and 7, small unidentified flagellates $(<10 \mu \mathrm{m})$ and diatoms (primarily represented by Pseudo-nitzchia species) were dominant respectively.

Azadinium-like cells were found at temperatures ranging from 5 to $11.5^{\circ} \mathrm{C}$ and at salinities ranging from 32.9 to 34.1 . Maximum Azadinium-like cell densities were found at temperatures between 11.1 and $11.4^{\circ} \mathrm{C}$ and at a salinity of 33 . The temperature range of the whole expedition was $5-15^{\circ} \mathrm{C}$ and salinity ranged between 32.9 and 34.0. The low cell abundances did not allow further SEM analysis for species identification.

\section{Azaspiracids}

For all four expeditions, AZA analysis of bottle samples were negative with the limits of detection of 43, 37-444, 59-89 and 26-132 $\mathrm{pg} \mathrm{L}^{-1}$ for E1, E2, E3 and E4 respectively. However, AZA-2 was detected in spring 2013 (E3) in plankton pellets obtained from 11 net samples corresponding to the 20- to $50-\mu \mathrm{m}$ size fraction and from another 11 net samples corresponding to the 50- to $200-\mu \mathrm{m}$ size fraction. AZA-2 was detected at stations located in slope waters from 39 to $40^{\circ} \mathrm{S}$ and from 44 to $45^{\circ} \mathrm{S}$, from San Matías and Nuevo Gulfs and southern Buenos Aires Province (Fig. 5b). AZA-2 abundances ranged between 29 and $1244 \mathrm{pg}$ per net tow. Plankton net sample AZA concentrations 


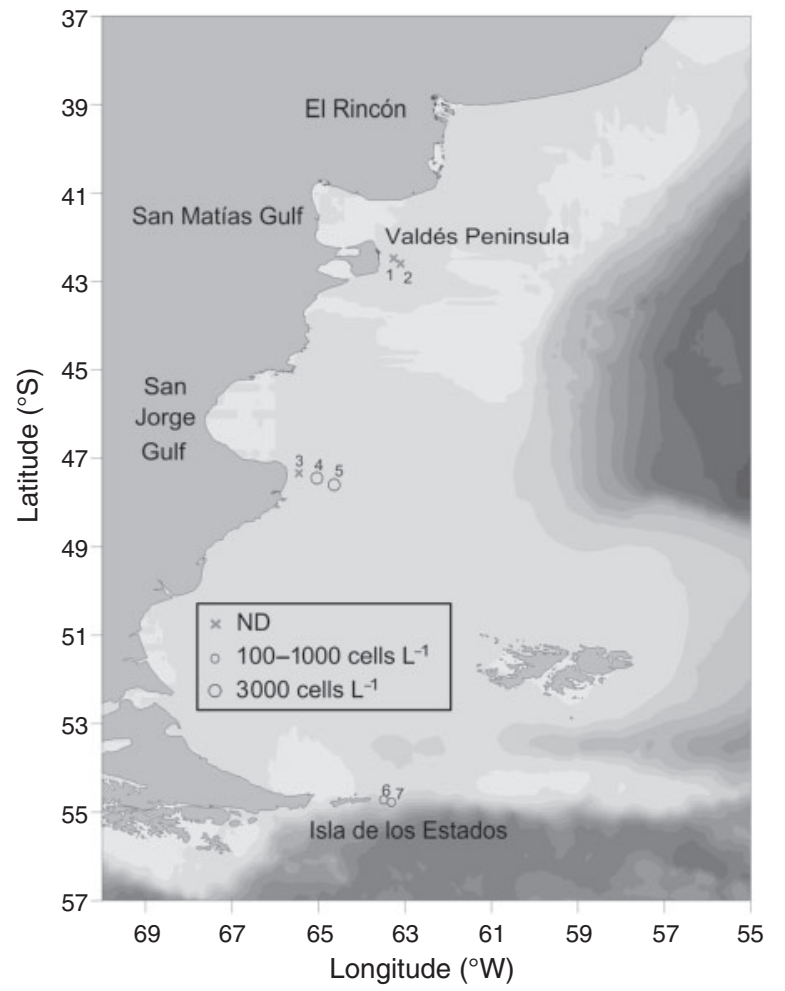

Fig. 6. Distribution and abundance of Azadinium-like cells in bottle samples from the early summer 2014 expedition (Expedition 4). ND, not detected.

from the other three expeditions were below the limit of detection of $\sim 30$ pg per net tow.

\section{Discussion}

\section{Azadinium diversity}

The microscopic identification of Azadinium species in field samples is difficult, especially when cell densities are low and different species occur in the same area. Moreover, species identification in most cases is impossible using light microscopy only (Tillmann et al. 2010, 2011, 2012b). In the present study it was possible to identify five Azadinium species by concentration of Niskin bottle samples and further SEM analysis.

Az. obesum was described based on a North Sea strain (Tillmann et al. 2010). This species is known to occur in the North Atlantic (Tillmann et al. 2018b) and north-east Pacific (Kim et al. 2017), and the present record is the first detection of Az. obesum in the Southern Hemisphere. None of the cultured strains of this species produced AZA analogues detectable by LC-MS/MS (Tillmann et al. 2010, 2018b; Kim et al. 2017).

Az. luciferelloides was recently described based on a field sample collected during an Amphidomataceae bloom that occurred in the 1990s in Argentinean slope waters. This species was the most abundant of all Amphidomataceae cells in that sample (Tillmann and Akselman 2016). Although there are another three Azadinium species (Az. caudatum, Az. dexteroporum and Az. concinnum) that, like Az. luciferelloides, have a vp in the right region of the Po (Tillmann and Akselman 2016),
Az. caudatum is significantly larger than Az. luciferelloides and has a different cell shape, $A z$. dexteroporum has a vp located at the end of an asymmetrical elongation of the pore plate and $A z$. concinnum has very large and symmetric precingular plates and very small apical plates (Tillmann et al. 2014a). The size range of Az. luciferelloides estimated here (7.4-13.6 $\mu \mathrm{m}$ long, 4.8-10.2 $\mu \mathrm{m}$ wide) is similar to the size reported in the species description (6.4-14.1 $\mu \mathrm{m}$ long, 7.6-11.6 $\mu \mathrm{m}$ wide; Tillmann and Akselman 2016). Az. luciferelloides was detected during the spring expedition in southern slope waters at $40^{\circ} \mathrm{S}$ in two samples in which it was the only species identified and the abundance of Azadinium-like cells was high $\left(30 \times 10^{3}\right.$ cells L $\left.^{-1}\right)$. This confirms that this species is an important member of the Azadinium spring communities in Argentina. Interestingly, Az. luciferelloides has a wide distribution, ranging from cool slope Argentinean waters (Tillmann and Akselman 2016; present study) to tropical Brazilian waters (Cavalcante et al. 2018). No cultured strain of the species is available yet, so its potential for AZA production is unclear.

During E1 and E3, the presence of Az. dexteroporum was confirmed for slope waters close to the site of the 1991 bloom $\left(\sim 38^{\circ} \mathrm{S}\right)$ and in the southern Argentine Sea (44 and $\left.55^{\circ} \mathrm{S}\right)$. The species $A z$. dexteroporum was described based on a strain isolated from the Gulf of Naples in the Mediterranean Sea (Percopo et al. 2013). Tillmann and Akselman (2016) found this species as part of the 1991 bloom in the Argentine Sea, although it was present in low abundance relative to total Amphidomataceae cells. In accordance with Tillmann and Akselman (2016), the cells observed in the present study had a vp located closer to the Po than specimens from the Mediterranean Sea (Percopo et al. 2013). The toxin-producing potential of $A z$. dexteroporum remains uncertain at the moment: culture of the Mediterranean type showed production of AZA-35 in addition to six compounds that represented new additions to the AZA group of toxins (Rossi et al. 2017), whereas no AZAs were detected in an Iceland strain isolated from the Irminger Sea (Tillmann et al. 2015). None of the recently described AZA analogues (i.e. AZA-54-58) produced by Mediterranean isolates of A. dexteroporum (Rossi et al. 2017) were found in the present study, despite the presence of this species in field samples. Therefore, the Argentinean populations of A. dexteroporum do not appear to be AZA-producing strains, similar to the strains isolated from Iceland (Tillmann et al. 2015), but confirmation by testing local strains is needed.

The latest described Azadinium species, Az. asperum (Tillmann 2018), was detected in the present study in slope waters of the northern sampling area in accordance with its type locality (Tillmann 2018). No cultured strain of the species is available yet, so the potential for producing AZA is unclear.

In SEM preparations of field samples, most amphidomatacean cells were impossible to identify at a species level because the plates are wrinkled, cells are deformed or oriented in such a way on the filter that important morphological details are hidden. Among those cells, three specimens visible in antapical view attracted our attention because of the presence of a distinct field of pores and a lack of an antapical spine on the second antapical plate. Such a group of pores was also found in Argentinean Az. poporum strains (Tillmann et al. 2016) and in Az. poporum from China (Gu et al. 2013), the Gulf of Mexico 
(Luo et al. 2016) and the Mediterranean (Luo et al. 2017). Although no other diagnostic traits for Az. poporum (i.e. position of the vp, presence of four apical plates to differentiate Az. poporum from Az. dalianense) were visible for any of the Argentinean field sample specimens, we used the presence of a group of pores and the absence of an antapical spine as evidence to classify these specimens as $A z$. cf. poporum. Such cells were detected in samples from external shelf waters at 55 and $40^{\circ} \mathrm{S}$ during E1 and E3 respectively. The presence of Az. poporum in Argentina is known from local strains (Tillmann et al. 2016) and from positive PCR assays using specific primers and probes (Tillmann et al. 2019).

Information from the present study together with previous reports (Tillmann and Akselman 2016; Tillmann et al. 2016, 2019; Tillmann 2018) highlights the Argentine Sea as an area harbouring quite a diverse range of Azadinium species, considering that 6 of the 13 species are recorded from this region and that 2 were actually described from Argentinean field samples. Conversely, other Amphidomataceae species (i.e. Am. languida, Am. parvula, Am. cyclops, Am. alata, Am. trioculata, Az. spinosum and $A z$. dalianense) previously recorded from the exceptional 1990-91 blooms or by the establishment of cell cultures and the use of molecular markers (Tillmann and Akselman 2016; Tillmann et al. 2018a, 2019; Tillmann 2018) were not detected in the present study. The fact that they were not found in SEM analysis of our field samples could be the result of their presence in very low abundances.

\section{Azadinium and AZA distribution}

Despite the importance of detecting and quantifying toxigenic species in the field, studies about the spatial and temporal dynamics of Azadinium species are scarce. In the Argentine Sea, there are few Amphidomatacean reports since the work of Akselman and Negri (2012) and Akselman et al. (2014), who registered three intense Azadinium blooms in the 1990s, two of them during spring and one during late winter, in middle shelf waters adjacent to the front of El Rincón and in slope waters. Recently, a spring expedition revealed Amphidomatacean densities up to $2.8 \times 10^{5}$ cells $\mathrm{L}^{-1}$ at El Rincón in 2015 (Tillmann et al. 2019). The idea that the shelf front of the Argentine coast in spring is a hot spot for amphidomatacean species is supported by the present results, with maximum Azadinium-like cell densities found in northern slope and external shelf waters during spring.

Based on various sampling cruises, Akselman et al. (2014) determined that Azadinium, albeit at rather low abundances $\left(<1 \times 10^{3}\right.$ cells $\left.\mathrm{L}^{-1}\right)$, has a very wide distribution in Argentine waters encompassing northern Argentine and southern Uruguayan shelves, including the mouth of the Río de la Plata (Akselman et al. 2014). Similarly, Antacli et al. (2018) found unidentified amphidomatacean cells in abundances $<10^{3}$ cells $\mathrm{L}^{-1}$ but widely distributed in the southern Argentine Sea, from $\sim 47$ to $53^{\circ} \mathrm{S}$. Our results suggest that amphidomatacean species are a regular component of phytoplankton in the area, showing a wide latitudinal distribution from 38 to $55.5^{\circ} \mathrm{S}$ and covering a wide range of temperatures $\left(5-19^{\circ} \mathrm{C}\right)$ and salinities (31-34). Moreover, we confirmed Azadinium occurrence in the southern Argentine Sea $\left(\sim 55^{\circ} \mathrm{S}\right)$. Maximum Azadinium-like cell abundance was found in very diverse plankton assemblages dominated by either diatoms or dinoflagellates or small phytoflagellates (including haptophytes) and cryptophytes. The highest Azadinium-like abundance $\left(\sim 1.5 \times 10^{5}\right.$ cells $\left.\mathrm{L}^{-1}\right)$ was recorded in waters with low temperature $\left(9-10^{\circ} \mathrm{C}\right)$ and high salinity (33.70; Fig. 7). Similar conditions occurred during the Amphidomataceae blooms from the $1990 \mathrm{~s}$ (temperatures $7.7-9.2^{\circ} \mathrm{C}$ and salinity 33.64-33.75; Akselman and Negri 2012), as well as during recent blooms on the external shelf and slope of El Rincón (temperatures $8-10^{\circ} \mathrm{C}$; Tillmann et al. 2019). By contrast, in Brazilian coastal waters (temperatures $16-22^{\circ} \mathrm{S}$ ), Cavalcante et al. (2018) found maximum Azadinium spp. (Az. dexteroporum, Az. polongum and Az. luciferelloides) cell densities at temperatures between 21 and $28^{\circ} \mathrm{C}$, although these densities $\left(6174\right.$ cells $\left.\mathrm{L}^{-1}\right)$ were lower than those detected in the present study. Conversely, the occurrence of Azadinium in low abundances has been recorded in cold waters $\left(<12^{\circ} \mathrm{C}\right)$ from the Northern Hemisphere, in the subpolar area of the Irminger Sea and northern Atlantic Ocean off Iceland (Tillmann et al. 2014a), as well as from the Shetland Islands (Tillmann et al. 2012b). However, the species found in those studies (Azadinium trinitatum, Az. concinnum, Azadinium cuneatum, Az. spinosum and Az. polongum) were not detected in the present study. There are limited data on the growth of Azadinium based on culture experiments: a North Sea strain of Az. spinosum showed a maximum grow rate at $22^{\circ} \mathrm{C}$ and a considerably lower growth rate at $10^{\circ} \mathrm{C}$ (Jauffrais et al. 2012). An Iceland strain of Az. polongum grew well at $10^{\circ} \mathrm{C}$, but died rapidly at higher temperatures (Tillmann et al. 2012b). Based on these different experimental responses to temperature, it could be expected that Azadinium species have distinct species distribution patterns. However, field studies about the spatial and temporal dynamics of Azadinium species are still scarce because of their small size and the impossibility of an accurate identification during cell counting under light microscopy. Finally, we cannot rule out that other factors may have a greater effect than temperature on the exceptionally high abundance of Amphidomataceae in the shelf break and El Rincon fronts of the Argentine Sea (e.g. nutrient supply given by the particular oceanographic characteristics of those areas; Acha et al. 2004).

Despite the fairly high cell densities of Azadinium-like cells reported here, no AZAs were detected in any of the bottle samples. For many samples with a low abundance of Azadinium-like cells, this could be due to the chemical detection limit, which, assuming a mean AZA cell quota of $10 \mathrm{fg} \mathrm{cell}^{-1}$ (Tillmann et al. 2014b), would require minimum densities of 2600-44 400 cells L ${ }^{-1}$ (depending on detection limits for each expedition) of a toxigenic species to be detected. A lack of AZAs in the high-abundance samples indicates that the dominant species in these populations do not produce any of the AZA congeners analysed. In fact, from 13 species of Amphidomataceae tested so far, AZA production has been proven for only four (Tillmann et al. 2009; Krock et al. 2012; Rossi et al. 2017). However, it is important to consider that Az. luciferelloides and Az. asperum were described based on Argentinean field samples (Tillmann and Akselman 2016; Tillmann 2018) and thus, because of a lack of cultures, their AZA production potential has not yet been tested.

The toxinological analysis of concentrated plankton net samples obtained during E3 showed the presence of AZA-2 from field plankton samples for the first time in the region. 


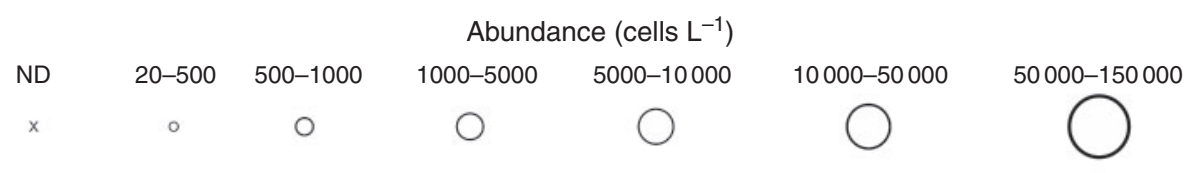

(a) 35
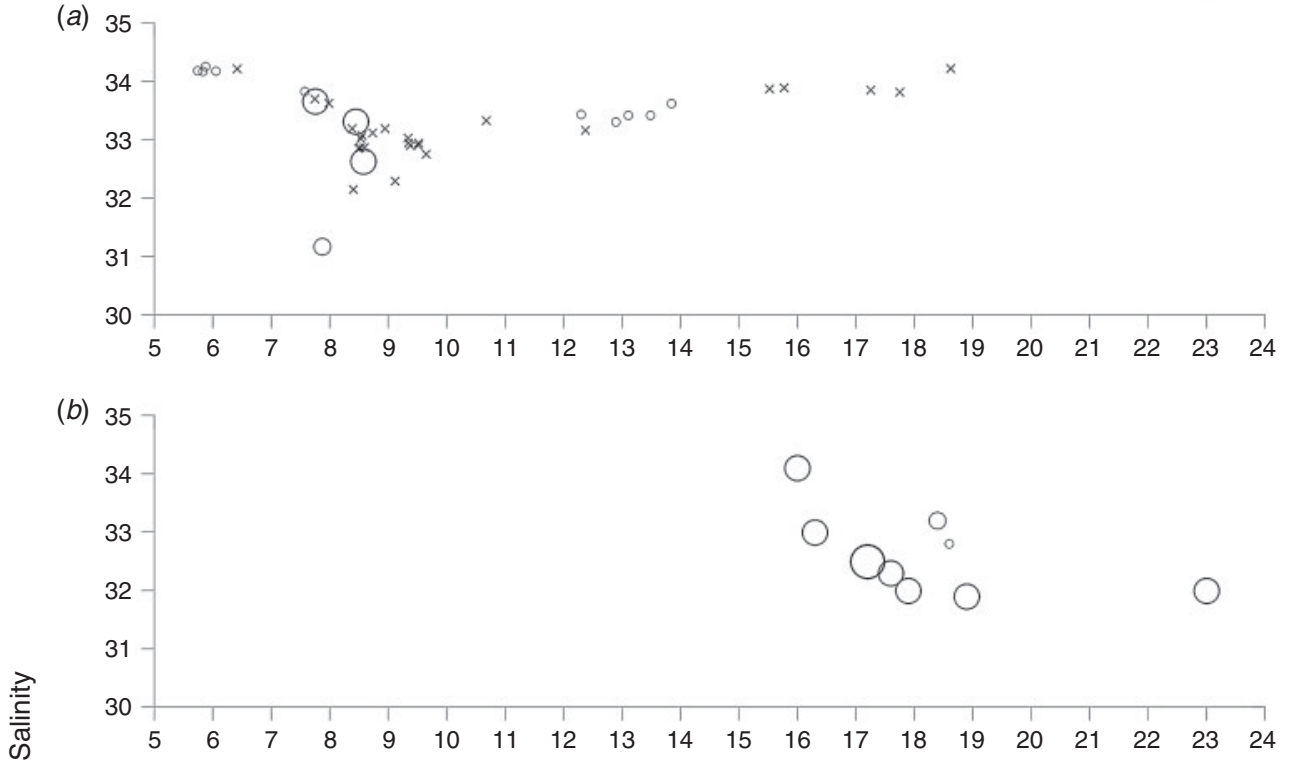

(c) 35

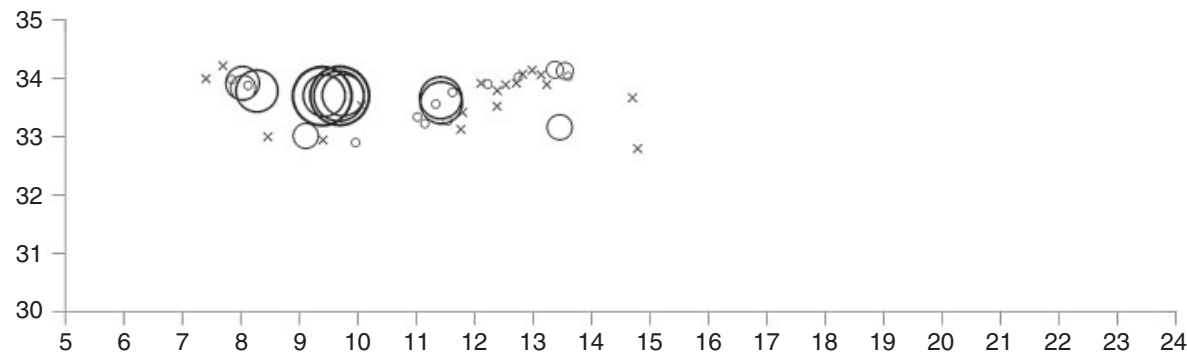

(d)

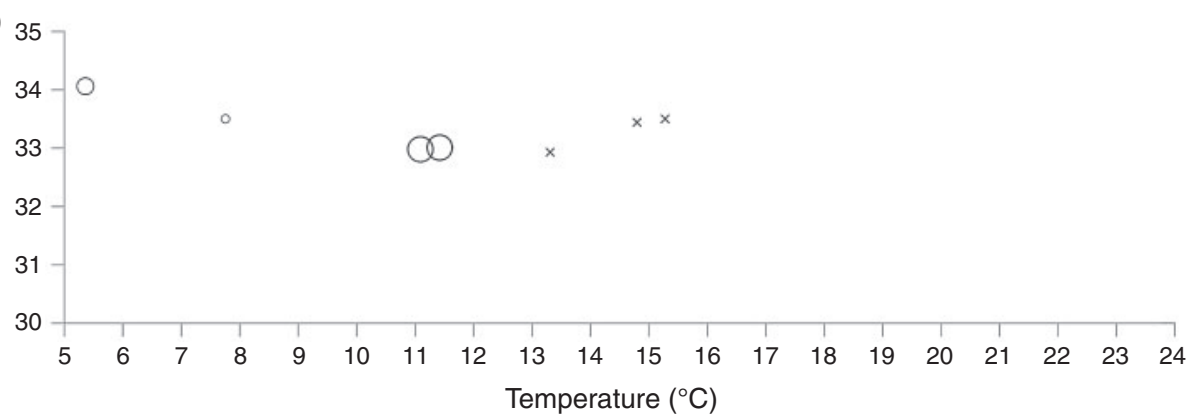

Fig. 7. Abundance of Azadinium-like cells at different surface salinities and temperatures for the four expeditions across the Argentine Sea: (a) Expedition 1, (b) Expedition 2, (c) Expedition 3 and (d) Expedition 4.

Despite the presence of a few Azadinium cells in these plankton net samples, it is assumed that the large majority of toxin was transferred to predators of Azadinium and other protistan grazers. AZA transmission through the food web is known for heterotrophic dinoflagellates and ciliates (Yasumoto 2001; James et al. 2003; Krock et al. 2008). Moreover, planktonic grazing on Azadinium has been suggested as an important loss factor during Azadinium blooms (Akselman and Negri 2012).
In the present study, potential AZA vectors, such as aloricate ciliates, tintinnids and heterotrophic dinoflagellates of the genera Protoperidinium and Gyrodinium, were detected as frequent components of microplankton during E3. Moreover, maximum Azadinium-like abundance co-occurred with the maximum density of G. fusus, a suspected predator of Azadinium sp. (Akselman and Negri 2012), in a sample where AZA-2 was also detected. 
Of the 21 AZA analogues analysed in this study, only AZA-2 was detected; the same analogue was exclusively found by Turner and Goya (2015) in mussels collected in Buenos Aires Province (although those authors only analysed AZA analogues 1-3). AZA-2 is known to be produced by Az. spinosum, Az. poporum and Am. languida. Of those, until recently only Az. poporum, and here including all Argentinean Az. poporum strains (Tillmann et al. 2016), was known to produce only AZA-2, whereas strains of Az. spinosum were characterised as producing AZA-1 together with AZA-2, and Am. languida was characterised as producing AZA-43 together with AZA-2. However, one of many Az. spinosum strains recently isolated from the Argentinean shelf was shown to represent the new ribotype B and to produce only AZA-2 (Tillmann et al. 2019). Thus, the presence of just AZA-2 in plankton samples (present study) and in Argentinean shellfish (Turner and Goya 2015) perfectly fits the toxin profile of Argentinean Azadinium strains available so far, but it is not possible to assign the presence of AZA-2 exclusively to Az. poporum or Az. spinosum.

\section{Conclusions}

This paper presents the first record of AZA-2 in plankton samples from Argentinean shelf waters, and the first detection of Az. obesum in the Southern Hemisphere in addition to four other Azadinium species, of which two are potentially toxigenic. Considering that the Atlantic coast of Argentina is a very important region for fisheries and seafood production (Bogazzi et al. 2005), the diversity, wide latitudinal distribution and high abundances of Azadinium, together with the detection of AZA2 , highlights the potential risk of AZA shellfish contamination episodes. There is a need for more toxinological information and spatiotemporal distribution data, as well as identification of possible source species of AZA in the study area.

\section{Conflicts of interest}

The authors declare that they have no conflicts of interest.

\section{Declaration of funding}

This work was partially financed by the Helmholtz-Gemeinschaft Deutscher Forschungszentren through the research program PACES of the Alfred-Wegener-Institut, Helmholtz Zentrum für Polar- und Meeresforschung and the binational project Ministerio de Ciencia y Tecnología (MINCyT)-Bundesministerium für Bildung und Forschung (BMBF) (AL/11/03-ARG 11/021). In addition, the study was supported by grants from Consejo Nacional de Investigaciones Científicas y Técnicas (CONICET; PIP 0173) and Agencia Nacional de Promoción Científica y Tecnológica (ANPCyT) (PICT 0576), as well as by the European Commission under the 7th Framework Programme through the Action-IMCONet (FP7 IRSES, Action number 319718).

\section{Acknowledgements}

The authors thank Wolfgang Drebing (Alfred-Wegener-Institut) for sample extraction and toxin measurements by LC-MS/MS. In addition, the friendly reception and support of the crew of the R/V Puerto Deseado (CONICETMINDEF, Argentina) in 2012 and 2013 and of the $R / V$ Bernardo Houssay (Prefectura Naval Argentina) in 2013 and 2016 are gratefully acknowledged.

\section{References}

Acha, E. M., Mianzan, H. W., Guerreroa, R. A., Favero, M., and Bava, J. (2004). Marine fronts at the continental shelves of austral South America: physical and ecological processes. Journal of Marine Systems 44(1-2), 83-105. doi:10.1016/J.JMARSYS.2003.09.005

Akselman, R., and Negri, A. (2012). Blooms of Azadinium cf. spinosum Elbrächter et Tillmann (Dinophyceae) in northern shelf waters of Argentina, Southwestern Atlantic. Harmful Algae 19, 30-38. doi:10. 1016/J.HAL.2012.05.004

Akselman, R., Negri, R. M., and Cozzolino, E. (2014). Azadinium (Amphidomataceae, Dinophyceae) in the Southwest Atlantic: in situ and satellite observations. Revista de Biología Marina y Oceanografía 49, 511-526. doi:10.4067/S0718-19572014000300008

Álvarez, G., Uribe, E., Ávalos, P., Mariño, C., and Blanco, J. (2010). First identification of azaspiracid and spirolides in Mesodesma donacium and Mulinia edulis from Northern Chile. Toxicon 55, 638-641. doi:10.1016/ J.TOXICON.2009.07.014

Antacli, J. C., Silva, R. I., Jaureguizar, A. J., Hernández, D. R., Mendiolar, M., Sabatini, M. E., and Akselman, R. (2018). Phytoplankton and protozooplankton on the southern Patagonian shelf (Argentina, $47^{\circ}-$ $55^{\circ} \mathrm{S}$ ) in late summer: potentially toxic species and community assemblage structure linked to environmental features. Journal of Sea Research 140, 63-80. doi:10.1016/J.SEARES.2018.07.012

Bacchiocchi, S., Siracusa, M., Ruzzi, A., Gorbi, S., Ercolessi, M., Cosentino, M. A., Ammazzalorso, P., and Orletti, R. (2015). Two-year study of lipophilic marine toxin profile in mussels of the north-central Adriatic Sea: first report of azaspiracids in Mediterranean seafood. Toxicon 108, 115-125. doi:10.1016/J.TOXICON.2015.10.002

Balech, E. (1988). Los dinoflagelados del Atlántico Sudoccidental. Publicaciones Especiales. Instituto Español de Oceanografía, Madrid, Spain.

Bogazzi, E., Baldoni, A., Rivas, A., Martos, P., Reta, R., Orensanz, J. M., Lasta, M., and Dell'Arciprete, P. (2005). Spatial correspondence between areas of concentration of Patagonian scallop (Zygochlamys patagonica) and frontal systems in the Southwestern Atlantic. Fisheries Oceanography 14, 359-376. doi:10.1111/J.1365-2419.2005.00340.X

Braña Magdalena, A., Lehane, M., Krys, S., Fernández, M. L., Furey, A., and James, K. J. (2003). The first identification of azaspiracids in shellfish from France and Spain. Toxicon 42, 105-108. doi:10.1016/S00410101(03)00105-3

Campodónico, I., and Guzmán, L. (1974). Marea roja producida por Amphidoma sp. en el Estrecho de Magallanes. Instituto de la Patagonia, Punta Arenas 1/2, 209-213.

Cavalcante, K. P., Susini-Ribeiro, S. M. M., and Tillmann, U. (2018). First detection of Azadinium spp. (Amphidomataceae, Dinophyceae) in tropical coastal waters of Brazil. Brazilian Journal of Botany 41, 209218. doi: $10.1007 / \mathrm{S} 40415-017-0435-7$

Elgarch, A., Vale, P., Rifai, S., and Fassouane, A. (2008). Detection of diarrheic shellfish poisoning and azaspiracid toxins in Moroccan mussels: comparison of the LC-MS method with the commercial immunoassay kit. Marine Drugs 6, 587-594. doi:10.3390/MD6040587

Gu, H., Luo, Z., Krock, B., Witt, M., and Tillmann, U. (2013). Morphology, phylogeny and azaspiracid profile of Azadinium poporum (Dinophyceae) from the China Sea. Harmful Algae 21-22, 64-75. doi:10.1016/J.HAL.2012.11.009

James, K. J., Moroney, C., Roden, C., Satake, M., Yasumoto, T., Lehane, M., and Furey, A. (2003). Ubiquitous 'benign' alga emerges as the cause of shellfish contamination responsible for the human toxic syndrome, azaspiracid poisoning. Toxicon 41, 145-151. doi:10.1016/S00410101(02)00244-1

Jauffrais, T., Marcaillou, C., Herrenknecht, C., Truquet, P., Séchet, V., Nicolau, E., Tillmann, U., and Hess, P. (2012). Azaspiracid accumulation, detoxification and biotransformation in blue mussels (Mytilus edulis) experimentally fed Azadinium spinosum. Toxicon 60, 582-595. doi:10.1016/J.TOXICON.2012.04.351 
Kim, Y., Tillmann, U., Adams, N. G., Krock, B., Stutts, W. L., Deeds, J. R., Han, M. S., and Trainer, V. L. (2017). Identification of Azadinium species and a new azaspiracid in Puget Sound, Washington State, USA. Harmful Algae 68, 152-167. doi:10.1016/J.HAL.2017.08.004

Krock, B., Tillmann, U., John, U., and Cembella, A. D. (2008). LCMS/MS on board ship: tandem mass spectrometry in the search for phycotoxins and novel toxigenic plankton from the North Sea. Analytical and Bioanalytical Chemistry 392, 797-803. doi:10.1007/S00216-008-2221-7

Krock, B., Tillmann, U., Voß, D., Koch, B. P., Salas, R., Witt, M., Potvin, É., and Jeong, H. J. (2012). New azaspiracids in Amphidomataceae (Dinophyceae). Toxicon 60, 830-839. doi:10.1016/J.TOXICON.2012. 05.007

Krock, B., Tillmann, U., Witt, M., and Gu, H. (2014). Azaspiracid variability of Azadinium poporum (Dinophyceae) from the China Sea. Harmful Algae 36, 22-28. doi:10.1016/J.HAL.2014.04.012

Krock, B., Tillmann, U., Tebben, J., Trefault, N., and Gu, H. (2019). Two novel azaspiracids from Azadinium poporum, and a comprehensive compilation of azaspiracids produced by Amphidomataceae, (Dinophyceae). Harmful Algae 82, 1-8. doi:10.1016/J.HAL.2018.12.005

Lassus, P., Chomérat, N., Nézan, E., and Hess, P. (2016). 'Toxic and Harmful Microalgae of the World Ocean/Micro-Algues Toxiques et Nuisibles de 1'Océan Mondial.' (International Society for the Study of Harmful Algae (ISSHA) and Intergovernmental Oceanographic Commission of UNESCO: Copenhagen, Denmark.)

Luo, Z., Krock, B., Mertens, K. N., Price, A. M., Turner, R. E., Rabalais, N. N., and Gu, H. (2016). Morphology, molecular phylogeny and azaspiracid profile of Azadinium poporum (Dinophyceae) from the Gulf of Mexico. Harmful Algae 55, 56-65. doi:10.1016/J.HAL.2016.02.006

Luo, Z., Krock, B., Mertens, K. N., Nézan, E., Chomérat, N., Bilien, G., Tillmann, U., and Gu, H. (2017). Adding new pieces to the Azadinium (Dinophyceae) diversity and biogeography puzzle: non-toxigenic $A z a-$ dinium zhuanum sp. nov. from China, toxigenic $A$. poporum from the Mediterranean, and a non-toxigenic A. dalianense from the French Atlantic. Harmful Algae 66, 65-78. doi:10.1016/J.HAL.2017.05.001

Percopo, I., Siano, R., Rossi, R., Soprano, V., Sarno, D., and Zingone, A. (2013). A new potentially toxic Azadinium species (Dinophyceae) from the Mediterranean Sea, A. dexteroporum sp. nov. Journal of Phycology 49, 950-966.

Rossi, R., Dell'Aversano, C., Krock, B., Ciminiello, P., Percopo, I., Tillmann, U., Soprano, V., and Zingone, A. (2017). Mediterranean Azadinium dexteroporum (Dinophyceae) produces six novel azaspiracids and azaspiracid-35: a structural study by a multi-platform mass spectrometry approach. Analytical and Bioanalytical Chemistry 409(4), 1121-1134. doi:10.1007/S00216-016-0037-4

Satake, M., Ofuji, K., Naoki, H., James, K. J., Furey, A., McMahon, T., Silke, J., and Yasumoto, T. (1998). Azaspiracid, a new marine toxin having unique spiro ring assemblies, isolated from Irish mussels, Mytilus edulis. Journal of the American Society for Mass Spectrometry 120, 9967-9968.

Taleb, H., Vale, P., Amanhir, R., Benhadouch, A., Sagou, R., and Chafik, A. (2006). First detection of azaspirazids in mussels in north west Africa. Journal of Shellfish Research 25, 1067-1070. doi:10.2983/07308000(2006)25[1067:FDOAIM]2.0.CO;2

Tillmann, U. (2018). Electron microscopy of a 1991 spring plankton sample from the Argentinean Shelf reveals the presence of four new species of the Amphidomataceae (Dinophyceae). Phycology Research 66, 269290. doi:10.1111/PRE. 12225

Tillmann, U., and Akselman, R. (2016). Revisiting the 1991 algal bloom in shelf waters off Argentina: Azadinium luciferelloides sp nov. (Amphidomataceae, Dinophyceae) as the causative species in a diverse community of other amphidomataceans. Phycology Research 64, 160175. doi:10.1111/PRE. 12133

Tillmann, U., Elbrächter, M., Krock, B., John, U., and Cembella, A. (2009). Azadinium spinosum gen. et sp. nov. (Dinophyceae) identified as a primary producer of azaspiracid toxins. European Journal of Phycology 44, 63-79. doi:10.1080/09670260802578534

Tillmann, U., Elbrächter, M., John, U., Krock, B., and Cembella, A. (2010). Azadinium obesum (Dinophyceae), a new nontoxic species in the genus that can produce azaspiracid toxins. Phycologia 49(2), 169-182. doi:10. 2216/PH09-35.1

Tillmann, U., Elbrächter, M., John, U., and Krock, B. (2011). A new nontoxic species in the dinoflagellate genus Azadinium: A. poporum sp. nov. European Journal of Phycology 46(1), 74-87. doi:10.1080/09670262. 2011.556753

Tillmann, U., Salas, R., Gottschling, M., Krock, B., O’Driscoll, D., and Elbrächter, M. (2012a). Amphidoma languida sp. nov. (Dinophyceae) reveals a close relationship between Amphidoma and Azadinium. Protist 163(5), 701-719. doi:10.1016/J.PROTIS.2011.10.005

Tillmann, U., Soehner, S., Nézan, E., and Krock, B. (2012b). First record of Azadinium from the Shetland Islands including the description of A. polongum sp. nov. Harmful Algae 20, 142-155. doi:10.1016/J.HAL. 2012.10.001

Tillmann, U., Gottschling, M., Nézan, E., Krock, B., and Bilien, G. (2014a). Morphological and molecular characterization of three new Azadinium species (Amphidomataceae, Dinophyceae) from the Irminger Sea. Protist 165, 417-444. doi:10.1016/J.PROTIS.2014.04.004

Tillmann, U., Salas, R., Jauffrais, T., Hess, P., and Silke, J. (2014b). AZA: the producing organisms - biology and trophic transfer. In 'Seafood and Freshwater Toxins, Pharmacology, Physiology, and Detection', 3rd edn. (Ed. L. M. Botana.) pp. 773-798. (Taylor \& Francis: Boca Raton, FL, USA.)

Tillmann, U., Gottschling, M., Nézan, E., and Krock, B. (2015). First record of Azadinium dexteroporum and Amphidoma languida (Amphidomataceae, Dinophyceae) from the Irminger Sea off Iceland. Marine Biodiversity 8, 1-11.

Tillmann, U., Borel, C. M., Barrera, F., Lara, R., Krock, B., Almandoz, G. O., Witt, M., and Trefault, N. (2016). Azadinium poporum from the Argentine continental shelf, Southwestern Atlantic, produces azaspiracid-2 and azaspiracid-2 phosphate. Harmful Algae 51, 40-55. doi:10.1016/J.HAL.2015.11.001

Tillmann, U., Gottschling, M., Guinder, V., and Krock, B. (2018a). Amphidoma parvula (Amphidomataceae), a new planktonic dinophyte from the Argentine Sea. European Journal of Phycology 53, 14-28. doi:10. 1080/09670262.2017.1346205

Tillmann, U., Edvardsen, B., Krock, B., Smith, K. F., Paterson, R. F., and Voß, D. (2018b). Diversity, distribution, and azaspiracids of Amphidomataceae (Dinophyceae) along the Norwegian Coast. Harmful Algae 80, 15-34. doi:10.1016/J.HAL.2018.08.011

Tillmann, U., Gottschling, M., Krock, B., Smith, K. F., and Guinder, V. (2019). High abundance of Amphidomataceae (Dinophyceae) during the 2015 spring bloom of the Argentinean Shelf and a new, non-toxigenic ribotype of Azadinium spinosum. Harmful Algae 84, 244-260. doi:10. 1016/J.HAL.2019.01.008

Trainer, V. L., Moore, L., Bill, B. D., Adams, N. G., Harrington, N., Borchert, J., da Silva, D. A., and Eberhart, B. T. L. (2013). Diarrhetic shellfish toxins and other lipophilic toxins of human health concern in Washington state. Marine Drugs 11(6), 1815-1835. doi:10.3390/ MD11061815

Turner, A. D., and Goya, A. B. (2015). Occurrence and profiles of lipophilic toxins in shellfish harvested from Argentina. Toxicon 102, 32-42. doi:10.1016/J.TOXICON.2015.05.010

Twiner, M., Hess, P., and Doucette, G. J. (2014). Azaspiracids: toxicology, pharmacology, and risk assessment. In 'Seafood and Freshwater Toxins'. (Ed. L. M. Botana) pp. 823-855. (CRC Press: Boca Raton, FL, USA.)

Utermöhl, H. (1958). Zur Vervollkommnung der quantitativen Phytoplankton Methodik. Internationale Vereinigung für theoretische und angewandte Limnologie 9, 1-38. 
Vale, P., Biré, R., and Hess, P. (2008). Confirmation by LC-MS/MS of azaspiracids in shellfish from the Portuguese north-western coast. Toxicon 51, 1449-1456. doi:10.1016/J.TOXICON.2008.03.022

Yao, J., Tan, Z., Zhou, D., Guo, M., Xing, L., and Yang, S. (2010). Determination of azaspiracid-1 in shellfishes by liquid chromatography with tandem mass spectrometry. Se Pu 28, 363-367. doi:10.3724/SP.J. 1123.2010 .00363
Yasumoto, T. (2001). The chemistry and biological function of natural marine toxins. Chemical Record 1, 228-242. doi:10.1002/TCR.1010

Handling Editor: Daniel Roelke 